\title{
ACTUAL ISSUES OF CASH FLOW MANAGEMENT IN ENTERPRISES IN RUSSIA
}

\author{
Alla I.Podgornaya ${ }^{1}$ \\ Konstantin V. Romanov ${ }^{2}$
}

\begin{abstract}
In the modern economy, the problem of cash shortages in an enterprise is one of the key problems. Absence of cash shortages contributes to the smooth operation of enterprises and implementation of all types of activities by them. The main reason for the occurrence of a cash shortage, as a rule, is the low efficiency of managing and attracting cash flows, as well as the limitedness of methods, technologies

clarified; the problems of cash flow management are investigated. The main issues faced by modern Russian enterprises in the process of cash flow management are identified. The author's scheme of cash flow management is proposed taking into account external and internal factors and the financial strategy of an enterprise. The purpose of the study is to identify the main issues of cash flow management in Russia.
\end{abstract} and financial instruments for solving this task. Since methods and financial instruments are based on a theoretical basis, as well as on practical examples, their application and development are especially in demand. Therefore, the issue of cash flow management at Russian enterprises is relevant today. The paper explores current scientific discussions regarding the management of cash flows at an enterprise in Russia. The "cash flow" concept is

Keywords: cash flows, enterprise, financial management, cash flow management; the financial condition of an enterprise; risks.

\section{Introduction}

The relevance of cash flow management issue at Russian enterprises is justified, first of all, by the lack of cash and cash equivalents as one of the most acute problems at the enterprises. The

\footnotetext{
1 Kazan Federal University, Kazan, 420008, Russia. e-mail: oreola77@mail.ru. Tel.: 89179334990

2 Kazan Federal University, Kazan, 420008, Russia. e-mail: oreola77@mail.ru. Tel.: 89179334990
} 
deficit of free cash prevents smooth operation during the implementation of the main activities at the enterprise, and the lack of free cash leads to a reduction in investment activity.

The theoretical component of this work is based on the scientific works of foreign and domestic authors, such as I. Blank, N. Bagautdinova, A. Doronina, A. Podgornaya, E. Strelnik, E. Stoyanova, A. Sheremet, M. Porter, F. Kotler, E. Golubkov., D. Usanova, and others $[1,2,3]$.

The purpose of this paper is to identify the main issues of enterprise cash flow management in Russia.

\section{Methods}

When conducting the research, we used statistical methods, methods of strategic analysis, economic analysis of organizations as a toolkit, as well as such general scientific methods as analysis and synthesis, a systematic approach to studying the external and internal environment of the organization, socioeconomic phenomena and processes.

\section{Results And Discussion}

The study clarified the concept of "cash flow". There are many different interpretations of the "cash flows" concept. The most common are two main of them. One group of economists, when designating and calculating cash flow, relies on cash balances in the enterprise account until its further use. Based on this method of understanding cash flow, cash balance for the previous period +cash flow - cash outflow $=$ cash balance for the next reporting period [4]. Based on these considerations, we can conclude that cash flow is tightly connected with cash balances, both at the beginning and at the end of the period. Similar reasoning was used by the English economist P. Wilson. According to the author, such reasoning is not substantiated, because when calculating and understanding cash flows, it is first of all necessary to rely not on the balance sheet, but on the cash flow statement.

Another group of economists includes such scientists as I. Blank, E. Stoyanova, A. Sheremet and others. These scientists calculate cash flow as the difference between cash inflow and outflow. In our opinion, a similar method of determining and calculating cash flow is the most correct for Russian enterprises, because this definition most accurately reflects the result of economic activity and allows us to more accurately determine the structure of cash flow [5]. 
Thus, cash flow is the aggregate inflow and outflow of funds considered in a certain interval of time and received as a result of the financial and economic activities of an enterprise.

Actual problems of cash flow management are considered here. Cash flows are the clearest indicator of the economic status of an enterprise. The level of cash flows shows the ability of an enterprise to respond to the influence of external factors and represents the prospects for its further growth. [6]

Cash flow management is an essential element of an enterprise's financial policy; it permeates the entire enterprise management system. The importance and significance of cash flow management at the enterprise can hardly be overestimated since not only the stability of an enterprise in a specific period of time depends on its quality and effectiveness, but also the ability to further develop and achieve financial success for the long term [7]. At present, one of the most important problems of Russian enterprises is the problem of a lack of money funds, both in cash and non-cash form. Many even profitable and successful enterprises are close to bankruptcy due to the lack of available funds for the development of current and investment activities. For this reason, assessing the financial condition of an enterprise based on key indicators of financial stability is not entirely correct. Of course, the revenue and profit level assessment shows the current state of an enterprise; however, not even a significant interruption in the movement of cash flows will lead to a malfunction of the enterprise, and also to unplanned expenses and losses. As a result of the failure of the cash flow, productivity and the level of required reserves will suffer, which will entail a slowdown in the level of sales of products and other unforeseen expenses. All of the above will immediately cause external problems: violation of credit agreements, and also problems with investors and partners. If we evaluate the negative consequences of a violation of cash flows, then the main loss, in this case, will be deterioration in reputation. An economy devoid of reputational mechanisms tends to stagnate. [8] The event of interruptions in cash flow or an increase in cash outflows, of course, increases the risk of bankruptcy of the enterprise. In addition, a violation of the funds' movement entails a violation in the adoption of management decisions, which can lead to more serious 
consequences than changes in the movement of funds.

Modern economists pay special attention to cash flow management, but at the same time, they stably disagree, which reasons entail errors in the practical application of their recommendations, since the conditions of the economy make it necessary to take into account various external effects when planning cash flows. The causes of these effects are different: crisis, changes in resource bases, political aspects, etc. For a competent assessment, analysis and planning of cash flows, it is necessary to introduce risk assessment and analysis into the model, such as financial risks, inflation risks, bankruptcy risk, etc. The enterprise is particularly affected by inflation risks. [9] This type of risk is quite predictable, although constantly changing. Inflation risk has a significant impact on longterm contracts. In the process of economic activity, an enterprise performs many financial transactions. Each of these operations is affected to one degree or another by different types of risks. Any risk is the probability of an event that leads to losses, which means an increase in negative cash flow. In consequence of the above, we can conclude that when planning and modelling cash flow, it is necessary to take into account the impact of various types of risk.

In addition to risk accounting, it is necessary to clearly determine the adequate value of cash flows. The most common approach for calculating the cost of cash flow involves the use of basic formulas and real rates of return. At the initial stage of calculations, it is necessary to correctly determine the rate of return, and then substitute it in a formula that was selected depending on the purpose of the financial transaction.

Another method is based on deflation. This approach implies first determining the nominal accumulated value when using basic formulas, and then deflating to the inflation index and thus obtaining the real value. Next, we need to use the basic formulas, substituting the amount of money in place of the nominal accrued to determine the real rate. An important component for financial calculations is the correct determination of the risk level. This will help to correctly form the necessary level of profitability and avoid negative consequences for the financial and economic activities of the enterprise [10]. 


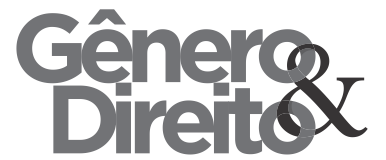

An equally important component in assessing cash flow is accounting for the liquidity of an enterprise in relation to the objects of investment and obtaining the planned rate of return. The rate of return should be taken into account, given the possible understatement of cash flow as a result of reinvestment.

One of the effective methods of cash flow management is the organization of the treasury. A centralized treasury is a treasury service organized in such a way that all financial flows go exclusively through it. Other departments of the enterprise participate in the process only by submitting applications for making payments, receipt plans and advising on the priority of payments. [11]

The centralized treasury unit manages the cash flows of the enterprise,
Periódico do Núcleo de Estudos e Pesquisas sobre Gênero e Direito

Centro de Ciências Jurídicas - Universidade Federal da Paraíba

V. 8 - No 05 - Ano 2019

ISSN | 2179-7137 | http://periodicos.ufpb.br/ojs2/index.php/ged/index

combines the functions of financial risk management, which greatly simplifies the planning of cash flows and reduces the risk of unplanned losses. The Central Treasury is responsible for: monitoring expenditure operations; cash flow budgeting; organization loan portfolio management. As a result of using the central treasury, the risks of overspending are minimized, the sequence of payments is optimized, an adequate operational plan is formed, expenses are optimized, and control over the fulfilment of credit obligations is improved. [12]

Thus, cash management can be divided into strategic and tactical. Figure 1 summarizes the cash flow management mechanism in accordance with the current financial strategy.

\begin{tabular}{|l|l|}
\hline Strategic cash flow management & Tactical cash flow management \\
\hline
\end{tabular}

\begin{tabular}{|l|l|lr|l|}
\hline $\begin{array}{l}\text { The value of } \\
\text { money in time; the }\end{array}$ & $\begin{array}{l}\text { Strategic financial } \\
\text { goal }\end{array}$ & $\begin{array}{l}\text { Cash } \\
\text { analysis; }\end{array}$ & & $\begin{array}{l}\text { Cash flow planning; } \\
\text { risk assessment and } \\
\text { analysis; outflow } \\
\text { control; creation of }\end{array}$ \\
\hline
\end{tabular}




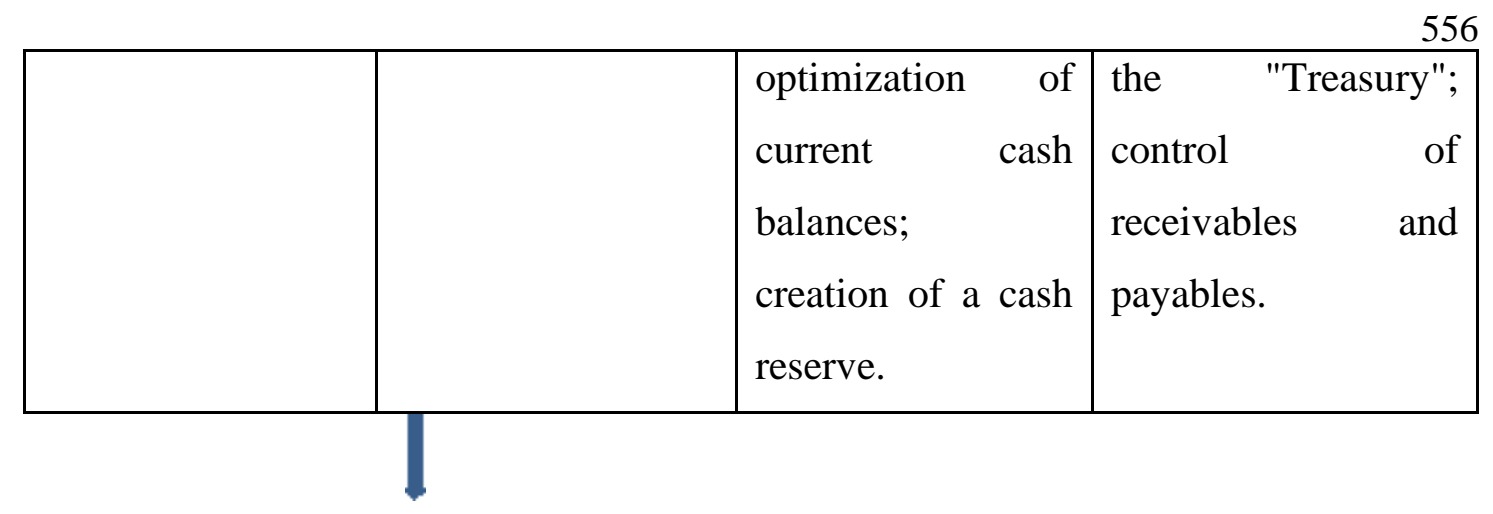

The financial
strategy of the
enterprise

Scheme 1. Enterprise cash flow management

Banking services have a major impact on cash flow. The enterprise management needs to choose the right bank based on the cost and timing of operations.

The effect of using borrowed financing instruments can be determined using an expanded interpretation of financial leverage:

$R O E=R O O A+\left(R O N O A-k_{d}\right) \times D / S$

$+\left(R O O A-k_{o} \times\right.$ OL / NOAX [1]

$D / S$ - financial leverage;

$O L / N O A$ - leverage for shortterm liabilities;

$k_{d}$ - post-tax rate on loans;

$\kappa_{o}$ - analytical rate on "interest-

free" obligations;

$$
k_{o} \leq k_{d}
$$

\section{Summary}

To summarize the study, we identify the main pressing issues of cash flow management.

1. The main reasons for the reduction in cash and cash equivalents are their improper use and low investment attractiveness of the enterprise. The most obvious reason for such shortcomings is the lack of financial solutions, tools and mechanisms that can replenish the most liquid assets.

2. Cash flow management of an enterprise is an integral part of financial management, which is based on the strategy goals chosen by the enterprise. Management of the enterprise's cash 
flows has a direct impact on the enterprise's activities, therefore, their analysis and planning should be considered as part of the planning of the enterprise's strategy.

3. The enterprise's goal is to make a profit and in the long term increase in the enterprise's value. To achieve this goal, a flexible and effective financial management system and a welldeveloped financial strategy are required. It is necessary not only strategic but also operational management of cash flows of the enterprise.

4. The rational use of cash and the formation of cash flows contribute to the smooth operation of the enterprise, namely, they influence the processes of sale, production, and therefore the operating cycle of the enterprise. Even a slight violation of cash flow, in relation to the amount or in time, inevitably violates the activities of the enterprise. Disruptions in cash inflows or an increase in outflows entail disruptions in the supply of raw materials, stocks, payment of wages or violation of settlements with counterparties.

5. Particular attention in the planning process and the formation of cash flows deserves the time aspect. Untimely receipt of even a sufficient amount of cash has the same adverse effect as nonreceipt of these funds.

6. Balanced cash management helps to reduce the operating cycle and, accordingly, accelerate the turnover of capital. This process significantly reduces the enterprise's need for borrowed and credit funds and contributes to additional income as a result of the formation of own funds and investment activities.

7. The effectiveness of measures aimed at planning the movement of cash flows has a direct impact on the liquidity, profitability and overall financial stability of an enterprise.

The reasons for the violation of cash flows lie in the lack of free cash, nonperformance by counterparties of their obligations or ineffective and improper use of the cash flows.

\section{Conclusion}

Cash flow management is a system of valuation methods and management decisions aimed at the formation, use and distribution of cash flows to organize financial growth and stability of an enterprise. All financial management systems are aimed, to one 
degree or another, at increasing profits or increasing the market value of the enterprise. To ensure the above goals, we need to achieve and maintain a constant financial balance of the enterprise, which provides stable positive net cash inflow. In addition to the main task of financial management, there are current tasks for cash flows:

a) The formation of the necessary-sufficient positive cash flow;

b) Optimization of the distribution of cash resources in accordance with current activities;

c) Ensuring the necessary level of financial stability, without losing the speed of development of the enterprise;

d) Supporting the required level of solvency of the enterprise;

e) Minimization of losses in the value of cash during use.

All the considered problems of enterprise cash flow management are closely interconnected, although some of them are of a multidirectional nature (for example, maintaining constant solvency and minimizing losses in the value of money in the process of their use). Therefore, in the process of enterprise cash flow management, individual tasks should be optimized among themselves for the most effective implementation of the enterprise's main goal.

For high-quality financial analysis and control over the financial situation, it is necessary to choose the right planning, control, information systems for process automation. Incorrect selection of mechanisms will immediately lead to unpredictable cash gaps. Lack of funds at the end of the billing period leads to non-fulfilment of financial obligations, loss of reputation and conflicts with suppliers and creditors. If we will not pay attention to oversights in the analysis and cash flow planning, a similar situation will repeat in the next billing period and, having accumulating it as a "snowball", will definitely lead the enterprise to bankruptcy.

Side effects of insufficient attention to the formation of cash flows are a decrease in liquidity, violation of payment terms for contractors and other creditors, and the attraction of additional funds. Even the presence of a complete budgeting system cannot guarantee the absence of cash gaps.

\section{Acknowledgements}

The work is performed according to the Russian Government 


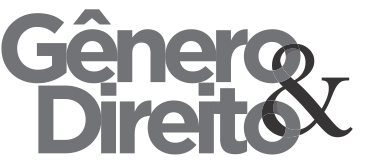

Periódico do Núcleo de Estudos e Pesquisas sobre Gênero e Direito Centro de Ciências Jurídicas - Universidade Federal da Paraíba V. 8 - $\mathrm{N}^{\circ} 05$ - Ano 2019 ISSN | 2179-7137 | http://periodicos.ufpb.br/ojs2/index.php/ged/index
Program of Competitive Growth of Kazan Federal University.

\section{References}

Bagautdinova N.G., Galieva G.T., Pakhmutov Ya.O., Pratchenko O.V.(2014). Methods of Regulation of Processes of Innovation Business Development. Mediterranean Journal of Social Sciences. Vol.5. No12. p.75-80.

Alla Podgornaya, Svetlana Grudina, Sofiya Avdonina. Anticrisis Potential Of Innovative Enterprises (Russia and Germany Case Study)//The Proceedings of 6th World Conference on Educational Sciences. (Malta 2 June 2015). - Volume 191. - P. 275 - 279.

Strelnik E.U, Usanova D.S, Khairullin I.G, Shafigullina G.I. , Khairullina K.T. Tax Burden in KPI system of corporation//Journal of Engineering and Applied Sciences. - 2018. - Vol.13, Is.2. - P.332-336.

Khoroshev, Mikhail. How to optimize the enterprise's cash management [electronic resource] M. Khoroshev Electronic Journal 75. Financial
Director, 2010. - Access mode: http://www.1fd.ru/, closed

I.A. Blank. Cash flow management. M. 2007 Publisher: Nika-Tsentr. Pp.137141.

A.I. Podgornaya, S.I. Grudina, S.G. Avdonina, An Enterprise Flexible Development Model //Procedia Economics and Finance Volume 24, 2015, Pages 519-522.

Berdnikova L.F., Khokhrina E.V. Influence of cash flows on the state and results of financial activity of an enterprise // Molodoy ucheny. - 2016. No. 16. - Pp. 137-141.

8. Gabdullin Nail, R. Vakhitov Damir, B. Zamaletdinov Aidar, N. Kondratyeva Tatiana Innovative Systems Influence on the Economic Growth of the Volga Federal District of the Russian Federation// Procedia Economics and Finance Volume 24, 2015, Pages 237-245 International Conference on Applied Economics (ICOAE) 2015, 2-4 July 2015, Kazan, Russia 
Bikchantaeva D.K. Modern approaches

to the management of sources of

financing / Bikchantaeva D.K.,

Guzelbaeva G.T. // Economics in a

changing world III All-Russian

Economic Forum with international

participation - Kazan 2019. - P.118 - 120.

Doronina A. I. Methods of analysis and optimization of cash flows in modern conditions // Young scientist. - 2016. No. 3. - Pp. 491-494.

Rybalko O. A. The concept of cash flows and their role in the management system [Text] // Economics, management, finances: materials IV international scientific conference (g. Perm, April 2015). - Perm: Zebra, 2015. Pp. 192194. 18.

Guzelbaeva G.T, Rakhmatullina D.K, Akhmetshina E.R., Evaluation of the implementation of entrepreneurial potential (on the example of the Republic of Tatarstan)//Journal of Physics: Conference Series. - 2017. - Vol.936, Is.1. - Art. № 012077 